\title{
PAULO FREIRE E A PESQUISA NARRATIVA (AUTO)BIOGRÁFICA: diálogos entre leitura do mundo, de si e de trajetórias de formação
}

\author{
Eda de Oliveira Henriques \\ Heriédna Cardoso Guimarães \\ Verônica Fabiola Neves Rodrigues
}

\section{Resumo}

Este texto tem como objetivo a construção de um diálogo entre o potencial investigativo e formador das narrativas no âmbito da Pesquisa Narrativa (Auto)Biográfica, e a contribuição de Paulo Freire para o que Ezequiel Theodoro da Silva, vai chamar de uma epistemologia da leitura. Para compor a tessitura dialogal entre os escritos de Paulo Freire e a Pesquisa Narrativa (Auto)Biográfica percorremos uma bibliografia sobre o pensamento freiriano no que se refere à de leitura de mundo e leitura da palavra e as reflexões de autores pioneiros da abordagem narrativa (auto)biográfica sobre as intercessões entre individual e coletivo e singular e social nas histórias de vida e formação. Compomos o texto em três partes, que, acompanhadas da introdução e considerações finais apresentam a concepção de leitura em Paulo Freire, a Pesquisa Narrativa (Auto)Biográfica como perspectiva de produção de pesquisas em educação e formação de professores, e a escrita dos memorias de formação como um dos possíveis, dentre outros, modos de conexão entre a leitura de si, leitura de mundo e da palavra nos processos de formação. A construção desse diálogo é enriquecedora para a Pesquisa Narrativa (Auto)Biográfica e amplia as ressonâncias entre a obra de Paulo Freire e seu caráter plural, não dicotômico, entre vida e obra, entre texto e contexto.

Palavras-chave: Paulo Freire; pesquisa narrativa (auto)biográfica; memoriais de formação.

\section{PAULO FREIRE AND (AUTO)BIOGRAPHICAL NARRATIVE RESEARCH:}

\author{
dialogues between reading the world, oneself and educational trajectories
}

\begin{abstract}
This text proposed the construction of a dialogue between the investigative and formative potential of narratives in the context of Narrative (Auto)Biographical Research and Paulo Freire's contribution to what Ezequiel Theodoro da Silva call an epistemology of reading. We present, from a bibliography, Freire's conception for word reading and world, and the reflections of pioneer authors of the narrative (auto)biographical approach about the intercessions between individual and collective, singular and social in the stories of life and formation. The text is composed in three parts, which, together with the introduction and final considerations, present Paulo Freire's conception of reading, Narrative (Auto)Biographical Research as a perspective of research production in education and teacher formation, and the writing of formation memorials as one of the possible ways, among others, of connecting the reading of self, reading of the world, and reading of the word in training processes. The construction of this dialogue is enriching for Narrative (Auto)Biographical Research and enlarge the resonances between Paulo Freire's work and its plural character, not dichotomous, between life and work, between text and context.
\end{abstract}

Keywords: Paulo Freire; narrative (auto)biographical research; formation memorials. 


\title{
PAULO FREIRE Y LA INVESTIGACIÓN (AUTO)BIOGRÁFICA NARRATIVA EN EDUCACIÓN:
}

\author{
diálogos entre la lectura del mundo, de uno mismo y las trayectorias formativas
}

Resumen

Este texto tiene como objetivo construir un diálogo entre el potencial investigativo y formativo de las narrativas en el contexto de la Investigación (Auto)Biográfica Narrativa y la contribución de Paulo Freire a lo que Ezequiel Theodoro da Silva llamará de una epistemología de la lectura. Para componer la tesitura dialógica entre los escritos de Paulo Freire y la Investigación (Auto)Biográfica Narrativa, se revisó una bibliografía sobre el pensamiento de Freire en términos de lectura del mundo y lectura de la palabra y las reflexiones de autores pioneros del enfoque (auto)biográfico narrativo sobre las intercesiones entre lo individual y lo colectivo y entre lo singular y lo social en las historias de vida y formación. Compusimos el texto en tres partes que, acompañadas de la introducción y consideraciones finales, presentan el concepto de lectura en Paulo Freire, la Investigación (Auto)Biográfica Narrativa como perspectiva para la producción de investigación en educación y formación docente, y la escritura de memoriales formativos como uno de los posibles, entre otros, modos de conexión entre leerse a sí mismo, leer el mundo y la palabra en los procesos de formación. La construcción de este diálogo es enriquecedora para la Investigación (Auto)Biográfica Narrativa y amplía las resonancias entre la obra de Paulo Freire y su carácter plural, no dicotómico, entre vida y obra, entre texto y contexto.

Palabras clave: Paulo Freire; investigación (auto)biográfica narrativa; memoriales formativos.

\section{INTRODUÇÃO}

Este artigo tem como objetivo tecer um diálogo e estabelecer relações entre o potencial investigativo e formador das narrativas no âmbito da Pesquisa Narrativa (Auto)Biográfica, dentro da perspectiva de uma nova epistemologia da formação (NOVOA, 2010) e uma concepção de leitura no pensamento freiriano, que de acordo com Silva (2011), vai remeter a uma epistemologia da leitura, a partir de concepções de homem, sociedade e educação.

Pensamos que esse diálogo pode se tornar profícuo e enriquecedor para uma concepção de pesquisa que tem uma de suas origens no âmbito da formação de adultos, dentro do movimento socioeducativo das histórias de vida e formação e têm como expressão emblemática um livro intitulado O Método (auto)biográfico e a formação, organizado por António Nóvoa e Matthias Finger (2010). Segundo o prefácio de Passeggi e Souza (2010), o livro traz textos de pioneiros deste movimento como Ferraroti, Pineau, Josso, entre outros, cujos escritos guardam o frescor e o entusiasmo que nos anos 1980 caracterizaram estas discussões. As questões trazidas no referido livro, têm como pano de fundo, principalmente via Ferraroti (2010), a necessidade de uma renovação metodológica, em função de que as grandes explicações estruturais, a partir de categorias muito gerais, não dão mais conta da compreensão de comportamentos individuais, de conhecimentos produzidos em trajetórias de vida e formação, onde desaguam questões muito caras à formação de professores como por exemplo: a escolha da profissão docente, a constituição de sentidos sobre a docência e suas implicações para o próprio exercício docente, entre outras.

Desta forma, ao atribuir valor de conhecimento à subjetividade, esta abordagem pretende compreender vários aspectos das histórias de vida e formação desses sujeitos a partir de suas próprias referências ao mesmo tempo singulares e sociais, permitindo a escuta de vozes silenciadas, a descoberta das sombras de cotidianos perdidos e de acontecimentos ignorados (AUTOR 1, 2018). Neste sentido, rompe a dicotomia singular e coletivo e reafirma que "pode-se ler uma sociedade através de uma biografia” (FERRAROTI, 2010, p.45). Assim, o indivíduo não interioriza o mundo, 
mas apropria-se dele em sua lógica individual, ou seja, o sujeito é um ser singular que apropria-se do social de uma forma específica, transfigurada em representações, aspirações, práticas, etc., a partir desta relação processual e dinâmica entre o singular e o universal social. Tal via não linear demanda a criação de novos olhares e novos métodos, mas sobretudo, segundo o autor, o reconhecimento de que uma narrativa biográfica não é um relatório de acontecimentos ou de experiências vividas, mas uma leitura de mundo que contêm, como um de seus desdobramentos e tessituras, histórias de vida e formação.

De acordo com Cunha (2010), quando alguém narra fatos e situações vividos, há uma reconstrução desta trajetória, onde são atribuídos novos significados ao caminho percorrido, possibilitando novas bases de compreensão do mesmo. Não é outra coisa que faz Freire (2011), em seu texto introdutório "A importância do ato de ler" no seu livro do mesmo nome, quando ele se propõe uma "releitura" de experiências remotas de sua infância e adolescência, buscando um olhar reflexivo e sempre aprendente, para a compreensão crítica da importância do ato de ler embebida no movimento "do mundo à palavra e da palavra ao mundo" (FREIRE, 2011, p. 29). O autor, em diferentes momentos de sua vasta obra, recorre ao uso da narrativa de momentos de sua história de vida e formação para atribuir sentidos ao dialogado, à mensagem a ser colocada em movimento.

No verbete sobre hermenêutica, escrito por Luiz Carlos Bombassaro (2008) para o dicionário Paulo Freire, é possível encontrar um delineamento sobre a relação entre os elementos da biografia (por nós considerada neste texto como narrativas de histórias de vida) e a produção da leitura de mundo. Esta que segundo a perspectiva freiriana, antecede a leitura da palavra, pois "a experiência de interpretação da realidade se realiza enquanto um processo compreensivo, que leva o homem a perceber a si mesmo e as suas circunstâncias, o mundo." (BOMBASSARO, 2008. p. 204). Nesta perspectiva, os elementos de nossas experiências de vida que são narrados, são produções de sentidos em torno dos contextos que nos atravessam e se constroem em diálogo com as nossas leituras de mundo e em especial de como nos tornamos e somos sujeitos nestes contextos.

É possível encontrar narrativas de Paulo Freire, excertos de narrativas de suas experiências vividas, no primeiro capítulo do livro Medo e Ousadia (2021) escrito com Ira Shor. Neste capítulo, Paulo Freire e Ira Shor, tentam responder as seguintes perguntas: como pode o professor transformar-se num educador libertador? De que modo a educação se relaciona com a mudança social? Como as respostas para ambas as perguntas são complexas, os autores partem de suas experiências de formação e de docência, narrando sobre como eram como professores iniciantes, os modos como ensinavam a gramática e a sintaxe e desse modo vão construindo reflexões acerca do como realizar a transformação do professor em educador libertador. Também somos presenteados com pequenas narrativas das experiências do 'andarilho da utopia' no livro Professora, sim; tia, não! (2021) em especial no capítulo que discute as relações entre ensinar e aprender. No livro Aprendendo com a própria bistória (2011) de autoria de Paulo Freire e Sérgio Guimarães, os autores vão, como aponta o próprio Freire, "escavando a memória" e por isso passam por experiências que envolvem o pré e pós anos 1964, anos emblemáticos e de exílio. E por fim, mas não esgotando o uso da memória, temos o livro Pedagogia da esperança: um reencontro com a pedagogia do oprimido (2021) que como nos diz Freire, não é "uma autobiografia. Não é um livro de memórias, mas um livro que tem memórias” (FREIRE; GUIMARÃES, 2011, p. 26).

Para Nóvoa (2010), as histórias de vida, e o então chamado método (auto)biográfico, estavam inseridos no movimento que procurava dar ao sujeito que se forma o protagonismo do processo, enfatizando que a formação é um trabalho de reflexão sobre os caminhos percorridos na vida, ou seja, um trabalho de apropriação retrospectiva de seus percursos de vida. Neste sentido, demanda um processo de contínua renovação, uma vez que essa retrospectiva pode se enriquecer, se modificar, quanto mais as possibilidades da relação entre a leitura da palavra e a leitura de mundo 
se ampliam. E nos parece que não é outra a intenção de Freire (2021) no diálogo com suas memórias, quando ele destaca que Pedagogia da esperança: um reencontro com a pedagogia do oprimido não é um livro de, mas um livro que tem memórias, que ecoam e se atualizam no presente do educador libertador. Portanto, tornar o sujeito ator de seu próprio processo de formação, confere ao mesmo estatuto de investigador, justificando para Nóvoa (2010), falar então de uma nova epistemologia da formação, que seguindo de perto a tradição freiriana, remete a um permanente processo de leitura e releitura, da palavra, do mundo e de si.

Considerando o exposto acima, esse texto se propõe a uma reflexão a partir da qual a rica concepção de Freire sobre uma ideia de leitura que transborda do mundo para palavra e da palavra para o mundo, pode potencializar ainda mais a narrativa no âmbito da pesquisa narrativa (auto)biográfica, como instrumento de produção de conhecimento, sobre si, sobre o outro e sobre as trajetórias de formação, estabelecendo pontes férteis entre os processos de autoformação e os processos de releitura de si e das experiências vividas.

Neste sentido, pretendemos aprofundar alguns pontos que remetem ao diálogo das relações entre releitura de si a partir da relação dinâmica entre leitura de mundo e leitura da palavra, a relação singular/coletivo em conexão com novas possibilidades de tessituras entre texto e contexto, a compreensão do pesquisador como um sujeito em permanente interlocução entre leituras de si e do mundo e as leituras das trajetórias de vida e formação dos sujeitos de sua pesquisa, viabilizando a construção de uma nova relação com o conhecimento e com os saberes produzidos ao longo dos processos de formação. Seguindo esse caminho de tessituras relacionais entre vida, leitura e formação apresentamos na terceira parte deste texto trechos de memoriais escritos por dois pesquisadores e suas reflexões sobre suas trajetórias de formação, analisando o que foi significativo neste processo. Os memoriais são um gênero acadêmico no qual predomina a escrita de si possibilitando ao ator/autor, narrar sua história de vida e seus percursos pessoais e profissionais (PASSEGGI; BARBOSA, 2008, p. 15). Nesta aventura narrativa nos apoiamos no legado do pensamento de Freire para reaprender a ler o mundo, nossos caminhos de formação e nossas relações com o conhecer e o pesquisar.

\section{UM CONCEITO DE LEITURA: LER O MUNDO E LER A PALAVRA VIA TRAJETÓRIAS DE FORMAÇÃO NO MUNDO}

A sensibilidade de Paulo Reglus Neves Freire se faz notar de forma intensa na dinâmica entre a narrativa como releitura de si e a "indicotomizável relação entre a leitura do mundo e a leitura da palavra" (SILVA, 2011, p. 10). No livro A importância do Ato de Ler, um dos mais célebres de Freire (2011), o autor, nos convida a vivenciar a sua narrativa sobre a leitura como acontecimento em sua vida, sua evolução da leitura de mundo e da palavra, nos mostrando como viveu e reviveu ao narrar esse processo multifacetado e instigante que é o ato de ler.

O encantador texto de Freire, através de sua "leitura" ou podemos dizer "narrativa" do mundo e da palavra, faz com que viajemos com ele a momentos de sua infância, adolescência, até a idade adulta e percebemos como foi se construindo no autor a necessidade de uma compreensão crítica da importância do ato de ler. O autor destaca em seu texto que "é como se eu estivesse fazendo a "arqueologia" de minha compreensão do complexo ato de ler, ao longo de minha experiência existencial” (FREIRE, 2011, p. 28).

A infância foi o lugar onde começou esta incrível experiência para o menino Paulo "primeiro, a 'leitura' do mundo, do pequeno mundo em que me movia; depois a leitura da palavra que nem sempre, ao longo de minha escolarização, foi a leitura da 'palavramundo"' (FREIRE, 
2011, p. 20). Nesta narrativa, o autor retoma sua infância em busca da compreensão de seu ato de ler, começa com a lembrança de sua casa na cidade do Recife, as árvores, o jardim, os animais, os medos infantis, o universo da linguagem dos mais velhos e tudo mais que compunha o mundo especial que "se dava a mim como o mundo de minha atividade perceptiva, por isso mesmo como o mundo de minhas primeiras leituras" (FREIRE, 2011, p. 21).

A narrativa de Freire nos envolve e nos faz retroagir no tempo, tanto o autor, quanto os leitores, pois, este movimento nos faz pensar sobre o nosso próprio desenvolvimento e consciência em relação ao ato de ler. Para o autor a leitura está ligada ao contexto e a compreensão que temos do mundo, ele deixa claro quando narra o seu encontro com a palavra escrita, "fui alfabetizado no chão do quintal de minha casa, à sombra das mangueiras, com palavras do meu mundo e não do mundo maior dos meus pais. O chão foi meu quadro-negro; gravetos o meu giz" (FREIRE, 2011, p. 24). Assim, não há como haver uma compreensão sobre as palavras escritas, sem essa leitura compreensiva sobre os acontecimentos que estão no mundo. Linguagem e a realidade se ligam no momento que através de uma leitura crítica fazemos relações entre o texto e o contexto.

Freire (2011), nos brinda com a sua retrospectiva pessoal do ato de ler, e como a prática da leitura o constituiu como homem, professor, formador e cidadão do mundo. Nesta relação, o autor narra sua leitura sobre o vivido, de tudo aquilo que perpassou todo seu corpo, produzido pelos sentidos, mas também pelos textos que se ofereciam à pesquisa, aos olhos de sua infância e mocidade, como uma ferramenta para suprir sua inquieta curiosidade sobre as coisas do mundo. O autor ao escrever a narrativa de suas experiências de leitura mostra nitidamente que este movimento de releitura de sua trajetória, um movimento retroativo, o levou a uma nova construção de saberes que "envolvia uma compreensão crítica do ato de ler, que não se esgota na decodificação pura da palavra escrita, ou da linguagem escrita, mas que se antecipa e se alonga na inteligência do mundo" (FREIRE, 2011, p. 19).

Leitura, segundo Silva (1991), é a participação crítica e ativa da comunicação humana, sendo possível apenas entre os homens. Podemos assim dizer que a leitura é um ato que transcende a leitura do signo atravessando este portal temporal e espacial das memórias e resgatando as narrativas em todo seu potencial formador. A concepção de leitura em Paulo Freire, possibilita a ampliação do sentido ato de ler. Podemos dizer que a leitura da 'palavramundo' é um ato que transcende a leitura do signo escrito, portanto o conceito de leitura freiriano abarca as dimensões da vida e não se restringe a uma codificação de signos, mas a sentimentos e reflexões que nos perpassam, que nos constituem. Porém, quais especificidades, delineamentos que o conceito de leitura como proposto por Paulo Freire nos auxiliam em reflexões sobre os nossos processos de formação?

Não há resposta única, porém podemos afirmar que todas as proposições passam pelo caráter emancipatório que a leitura da palavra, em situação imbricada, traz para a leitura de mundo, compondo a 'palavramundo'. A práxis presente no ler o mundo via a leitura da palavra (signo) é imperativa para a ação transformadora, inclusive para a educação que não muda o mundo sozinha, mas sem ela o mundo não se modifica. Envolta à ideia de leitura que atravessa a obra de Paulo Freire, é possível encontrar vários elementos, referenciais teóricos e epistemológicos ${ }^{1}$, experiências ${ }^{1}$ Leal e Nascimento (2019) apresentam no texto A importância do ato de ler: aproximações e distanciamentos teórico-metodológicos
em Paulo Freire algumas considerações sobre as influências teóricas e aproximações filosóficas que atravessam a obra de
Paulo Freire. Porém, não é objeto deste texto discutir ou apontar se Paulo Freire era marxista ou defensor absoluto da
fenomenologia, uma vez que, como sinaliza Walter Kohan $(2019$, p. 80 ), "a prioridade da vida é, para o Paulo Freire
filósofo, princípio não apenas de sua concepção de filosofia, mas também de educação e, de um modo mais geral, de
sua intelectualidade militante. Isso o faz ter uma postura crítica em relação à realidade educacional. Para dizer com
Paulo Freire, na escola (e na filosofia) existe uma dissociação crescente entre leitura das palavras e leitura de mundo 
que formaram o educador Paulo Freire; a teoria forjada na prática e a prática alimentada/transformada com e através da teoria, assim é a leitura. Lemos para fazer parte, pertencer ao mundo letrado, traduzir os nossos pequenos mundos, compreender o mundo com a sua poesia, suas histórias e trajetórias.

Ana Maria Freire (2015) quando escreve sobre texto e contexto na obra do autor, segue esse mesmo olhar e afirma que "o texto e o contexto e, portanto, o diálogo e a leitura de mundo em Freire, não se travam em campo neutro, alheio ao projeto de vida que cada um de nós tem, explicitem isso ou não" (FREIRE, Ana Maria, 2015, p.294). António Nóvoa (1992), ao discutir a formação docente afirma que "as opções que cada um de nós tem de fazer como professor, as quais cruzam nossa maneira de ser com a nossa maneira de ensinar e desvendam na nossa maneira de ensinar a nossa maneira de ser" (NÓVOA, 1992, p.17). Ler o mundo e formar-se a partir de sua leitura é parte do movimento de uma prática que não se desliga nem da teoria e nem da vida, mas voltam a elas para que a crítica consciente e fundamentada seja possível.

\section{AMPLIANDO AS POSSIBILIDADES DE LEITURA DA 'PALAVRAMUNDO' NAS TRAJETÓRIAS DE FORMAÇÃO}

Escrever e refletir em diálogo com os escritos de Paulo Freire é assumir, como ele mesmo propõe, que a leitura e a escrita são inseparáveis. Tal coexistência é processual e de longo tempo, pois "é preciso que o nosso corpo, que socialmente vai se tornando atuante, consciente, falante, leitor e 'escritor' se aproprie criticamente de sua forma de vir sendo que faz parte da sua natureza, histórica e socialmente construindo-se" (FREIRE, 2021, p.68). Atravessando as sincronias entre o ler e escrever temos os contextos, sendo estes importantes de modo que, quando adentramos um texto devemos compreendê-lo "na sua relação dialética com os seus contextos e o nosso contexto" (FREIRE, 1982, p.4). Isto porque, quando lemos/escrevemos/reescrevemos um texto estamos prenhes de nossas leituras de mundo, de nossas vivências que são conectadas via vida, textos, contextos, palavras, afinal "a leitura da palavra não é apenas precedida pela leitura do mundo, mas por uma certa forma de 'escrevê-lo' ou de 'reescreve-lo', quer dizer, de transformá-lo através de nossa prática consciente” (FREIRE, 1989, p.13).

Nesse movimento, compreender a leitura de mundo e da palavra, da 'palavramundo' (FREIRE, 2011, p. 20), em diálogo com Paulo Freire e lembrando que, como ele propõe, "não leio para formar-me; eu me formo também lendo", é criar paralelos, aproximações com as potencialidades formativas das narrativas de nossas histórias de vida, estas que como sinalizado na seção introdutória, são parte de uma nova epistemologia da formação. Formação que parte de nossas experiências, enxergando "a análise da memória e da narração como possibilidades emancipatórias do ser-professor/a, como ruptura com a racionalidade que percebe a docência reduzida a competência técnica" (BRAGANÇA, 2012, p.28). Parafraseando a afirmação de Freire, podemos dizer que não narramos para nos formar, mas também nos formamos enquanto narramos. Ao narrar construímos processos, movimentos compreensivos e contextuais em torno do como nos tornamos o que somos, como vimos a ser o que somos. Esses movimentos falam de relações singulares e coletivas porque, como nos indica Delory-Momberger (2012),

(FREIRE; SHOR, 1986, p. 85): as palavras que se leem na escola são palavras que já não dizem o mundo, que estão separadas do mundo vivido pelos que estão dentro da escola. A dupla consequência disso é que aprendemos a ler um mundo escolar que não é o que vivemos fora da escola e não aprendemos a ler esse mundo que vivemos fora da escola. O que lemos na escola não nos ajuda a ler o mundo; com as letras da escola não podemos ler a vida mundana." 
[...] as 'histórias' que contamos sobre nós mesmos e que, segundo alguns, nós dirigimos a outros, longe de nos jogar numa intimidade inacessível, têm por efeito articular nosso espaço-tempo individual ao espaço-tempo social. (DELORYMOMBERGER, 2012, p. 75).

E também nos articula enquanto pesquisadores aos sujeitos de nossas pesquisas. A pesquisa, nesta perspectiva, também promove uma produção de conhecimento através da inevitável interação que se produz entre pesquisador e pesquisado, fazendo com que em um movimento sempre aprendente, o pesquisador também se torne sujeito de sua pesquisa e se abra para o diálogo que se estabelece entre a leitura das trajetórias de formação no mundo do pesquisado e as leituras de suas próprias trajetórias de vida e de pesquisador.

\section{MEMORIAL DE FORMAÇÃO: UM EXERCÍCIO DE LEITURA DE MUNDO E DA PALAVRA NAS PESQUISAS SOBRE E COM A FORMAÇÃO DOCENTE}

De acordo com Cunha (2010), utilizar narrativas em propostas de pesquisa e/ou ensino, é trabalhar com um processo de construção/desconstrução de experiências que afeta a todos os envolvidos e encaminha para processos de reconstrução mútuos que afetam tanto pesquisadores e pesquisados como professores e alunos. O que provocaria mudanças nas percepções das pessoas sobre os outros, sobre si próprias, viabilizando um distanciamento da experiência vivida e uma outra possiblidade de "leitura" da mesma, abrindo caminho para um início de teorização. A autora destaca a relação dialética que se instala entre discurso e experiência, no sentido de que da mesma forma que a experiência produz o discurso, o discurso também produz experiência, ou poderíamos acrescentar, a experiência de transformar o vivido em uma narrativa.

A este respeito, Josso (2004), a partir de seus trabalhos sobre processos de formação, de conhecimento e de aprendizagem, segundo o ponto de vista dos aprendentes sobre suas experiências formadoras, nos diz que o vivido adquire o nível de experiência, a partir do momento que se realiza um trabalho de reflexão sobre o que foi observado, vivido e sentido. Assim, o processo de produção de uma narrativa ao demandar seleção de fatos a serem narrados, a ordem de sua importância e destaque, sua organização em um enredo, vai constituindo não só uma nova relação com sua trajetória, mas também a tomada de posse dessa trajetória, tornando o sujeito que narra, sujeito de sua própria história. Uma história que segundo Cunha (2010), foi de modo geral, silenciada no percurso cultural da escola, ajudando a produzir a ideia do distanciamento entre o saber cotidiano e o conhecimento científico. Para a autora, não se trata apenas de desconsiderar um conhecimento implícito nos múltiplos acontecimentos puxados pelos fios das narrativas, mas sim de ignorar as possibilidades significativas de produção de conhecimento através do diálogo entre a prática vivida e as construções teóricas em torno destas vivências. Seguindo a linha de pensamento de Cunha (2010), em diálogo com os preciosos ensinamentos de Freire sobre a importante relação entre leitura, narrativa e formação, poderíamos refletir que não basta dizer ao professor que tem que ensinar partindo da experiência dos alunos, se os programas que pensam sua formação não os reconhecem como leitores e narradores de sua própria história e saberes.

De acordo com Passeggi (2010), o memorial de formação é um texto acadêmico (auto)biográfico através do qual se analisa de forma reflexiva e crítica a trajetória de formação intelectual e profissional, esclarecendo o papel que pessoas, fatos e acontecimentos relatados incidiram sobre si, ampliando a consciência da historicidade das aprendizagens de si e de sua própria história. A autora assinala, que muitas instituições de ensino superior no Brasil, lançaram mão do memorial de formação como prática pedagógica e instrumento de avaliação. 


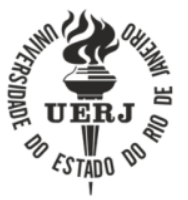

DOI: $10.12957 /$ teias.2021.62031

Alípio Casali (2012) ao fazer uma releitura dos usos da linguagem que Paulo Freire fez como educador ao longo de sua vasta obra, em especial os gêneros textuais por ele utilizados, destaca que o autor possuía familiaridade com diferentes gêneros e esse seu passeio textual tinha como principal motivo uma tentativa de aproximação para com o leitor. Casali (2012), sinaliza que é somente após retornar ao Brasil, período por ele denominado como quarto e último grande período da vida de Freire, que este se aproxima de uma escrita que se afasta do academicismo, "desdobrando-se em (auto)biografias, narrativas, memórias, entrevistas, diálogos, cartas, e que se têm mostrado como meios importantes para os processos de pesquisa, formação e ensino" (CASALI, 2012, p.66). Reencontrando e relendo os contextos brasileiros, Freire passeia pela escrita de cartas, diálogos, entrevistas, etc. e memoriais, pois para Alípio Casali (2012, p. 67) em 1982 quando Freire publicou a obra $A$ Importância do ato de ler ele publicou também um memorial, "um memorial de toda a experiência de alfabetização de adultos desenvolvida por ele e sua equipe em São Tomé e Príncipe." Outra escrita de memorial, cujas lembranças evocamos algumas vezes, ao longo deste texto, acontece em 1995 quando Freire:

[...] volta em sua memória à sua infância, à sombra das frondosas mangueiras, jaqueiras, cajueiros e pitombeiras do quintal de sua casa, no bairro da Casa Amarela, no Recife. O tema já havia sido objeto de intensa conversa entre Freire e Sérgio Guimarães (Sobre a Educação: Diálogos, 1982). Envolto pelos aromas e sabores de seu quintal de infância, Freire escreve o que talvez seja o seu memorial existencial mais denso, dois anos antes de sua morte: À sombra desta mangueira. (CASALI, 2021, p.68).

O memorial de formação, seguindo princípios e reflexões de significativos autores da abordagem da Pesquisa Narrativa (Auto)Biográfica como Nóvoa, Josso, Bragança, e também Paulo Freire, tem a importante função de colocar em diálogo palavras que se constituíram a partir destes autores para expressar uma ideia de indissociabilidade entre seus termos: 'palavramundo' (FREIRE, 2011) e pesquisaformação ${ }^{2}$ (BRAGANÇA, 2018; MOTTA; BRAGANÇA, 2019). Isto é, de contar, como nossos temas de pesquisa se entrelaçam com nossas trajetórias de vida e formação, com nossas 'palavrasmundo' e ao mesmo tempo que nos ajudam a compreender e aprender sobre aspectos dessa trajetória sobre os quais não havíamos percebido e refletido.

Para ilustrar essa questão, serão narrados a seguir trechos de dois memoriais produzidos em contextos de pesquisas de mestrado em Educação ${ }^{3}$, com comentários de suas autoras sobre a experiência de escrevê-los.

\footnotetext{
2 A opção pela grafia pesquisaformação dialoga com a justificativa apresentada em Nilda Alves (2008). A autora opta por escrever algumas palavras juntas porque este modo de escrever remete a uma compreensão que, partindo do caráter indissociável entre os termos, corrobora a crítica à dicotomização presente na ciência moderna. Inês Bragança (2018) ao traçar pistas sobre a Pesquisaformação narrativa (auto)biográfica afirma que estas estão inscritas no âmbito do movimento autobiográfico e são pesquisas que partindo das narrativas, compreendidas como fonte de pesquisa e de formação, entrelaça-se com a vida e com a reflexão que as histórias de vida inscritas social e politicamente suscitam, seja na produção da pesquisa, seja na trans/formação dos envolvidos. A pesquisaformação (pesquisa-formação) assume totalmente a presença e participação da pessoa que se forma no processo de feitura da pesquisa e o reconhece como autor de sua formação, legitimando a produção de saber sobre a sua prática e escolhas profissionais/pessoais, de modo que, "a compreensão da historicidade do sujeito e de suas aprendizagens, o percurso de formação e, sobretudo, de emancipação, promovida pela reflexividade autobiográfica que, superando a curiosidade ingênua, cede lugar a curiosidade epistemológica e a constituição da consciência crítica" (PASSEGGI; SOUZA, 2017, p.15) sejam centrais nos processos de formação de professores.

${ }^{3} \mathrm{Na}$ versão para publicação vamos inserir os títulos das dissertações vinculadas aos memoriais apresentados neste texto.
} 
Pesquisador 1 - trecho do memorial de formação de uma dissertação que pesquisou os sentidos produzidos para a docência em Física no Ensino Médio [...] no vivenciar das disciplinas, fui percebendo que a nossa formação não era de professores de Física para atuar no Ensino Médio e sim de físicos sem seus campos de atuação... quem produzia, criava, era o físico e não o futuro professor ou professor de Física do Ensino Médio. O meu compromisso era único e simplesmente reproduzir, da melhor maneira possível, os conteúdos a nós apresentados, e para isso minha formação foi e é muito boa. Quando concluí a graduação uma pergunta ficou: o que sou? Física? Não, não me reconheço como tal. Professora de Física do Ensino Médio? Tenho habilitação para desempenhar esta ação, mas não a exerço atualmente.

[No ano 2014 atuei] como professora de Física em turmas de Ensino Médio em escolas públicas de Niterói, na condição de contratação temporária. Eram três dias da semana, segunda, quarta e sexta; cada manhã em uma escola. Dois tempos de aula para rever os alunos, conversar com eles sobre avaliação, conteúdo, sobre a vida, escutar suas experiências com professores de Física antigos, escutar que não sabiam nada de Física e que era difícil, responder sobre o que fiz no cabelo, onde comprei a sandália nova, se tinha namorado, se eu ia participar da semana cultural, etc. e fazer a chamada de cinquenta e cinco nomes, pulando vários devido à ausência informada pelos alunos, quando eu chegava à Física, eu só tinha um tempo de aula, e aí era tudo corrido. Não consegui encontrar o equilíbrio e se encontrei não percebi.

A escola era um lugar comum, eu cresci ouvindo histórias de professores, e esta minha experiência era só mais uma igual a todas as outras que eu conhecia. A docência era isso: tentar ensinar e não conseguir, tentar dar aula com a participação dos alunos e não conseguir, tentar e não conseguir ser boa professora. Aceitar que essa sensação não é só sua e fazer o que for possível. Porém, eu não sabia ou não queria acreditar no que estava constatando? Ou os cinco anos de graduação em Física me fizeram esquecer que era assim? $\mathrm{O}$ incômodo que essa experiência como docente deixou em mim e a minha ausência de identificação com a profissão de físico são os elementos subjetivos e individuais que balizaram esta tentativa de reflexão sobre os caminhos da formação inicial de professores de Física do Ensino Médio, pois, independentemente dos problemas da escola ou da difícil situação de muitos alunos, eu sentia que havia um grande problema na minha formação, não só da graduação, mas também do que pude resgatar e lembrar das experiências com o ensino e aprendizagem da Física no Ensino Médio. (2018, p. 17)

Eu e minhas memórias na produção da pesquisa - Opto por assim nomear a relação que produzi ao reler meu memorial que se transformou no capítulo introdutório de minha dissertação de mestrado em educação defendida nos idos 2018 e origem do fragmento acima apresentado. $\mathrm{O}$ texto memorialístico/introdutório, buscava apresentar as diferentes vozes que ecoam na contextura da minha história de vida e formação como professora de física do ensino médio. Além de introduzir a minha dissertação, também apresentou o meu tema e objetivos da pesquisa, pois o tema da formação de professores de física que atuam no ensino médio partiu das minhas inquietações como graduanda, da não identificação com o perfil de formação que o meu diploma indicava. As reflexões acerca da não identificação com este perfil e de como a escola tornou-se distante para mim, só foram possíveis no processo de escrita do memorial.

Rememorar e escrever sobre as experiências de formação e de prática docente no contexto do memorial foi um movimento de atribuição de sentidos ao vivido, pois a inquietação com a 
minha experiência docente era sentida, mas não significada, como uma lacuna no meu processo de formação, como uma questão passível de ser estudada, e mais importante, como uma questão/inquietação que não era só minha, mas de muitos colegas de docência em física. $\mathrm{O}$ distanciamento entre formação e exercício docente que delineio neste excerto do memorial só ganhou esse contorno no processo de reflexão e escrita de respostas para a pergunta: como cheguei aos meus objetivos de pesquisa? Esta questão norteou a feitura da pesquisa e me ajudou a criar pontes entre as minhas experiências de formação e o exercício docente em física.

Escrever sobre o incômodo deixado pela reafirmação de que ao longo do curso "quem produzia, criava, era o físico e não o futuro professor de Física do Ensino Médio" foi emblemático para olhar as relações contextuais e de profissionalização da docência no âmbito da pesquisa, e em especial, em como os nossos professores formadores enxergam a docência. Também aprendemos o que Paulo Freire sempre considerou como fundamental para o professor, a constatação óbvia e simples de que estamos imersos no mundo, mediatizados pelos contextos, e deles não nos separamos. Realizamos ações que os modificam, porém ainda imersos neles e por isso aprender a ler, formar e tornar-se professor é a eles retomar sempre, mas munidos de novas palavras e leituras múltiplas.

Pesquisadora 2 - trecho de memorial de uma dissertação sobre a monitoria como processo de formação

Minha segunda experiência com a monitoria foi construída no ritmo do dia a dia comum a este Programa [de monitoria] e foi muito diferente da primeira experiência. Este momento de monitor era transformador, porque eu estava realmente experimentando o que era ser um profissional da educação, a sua rotina institucional, administrativa e emocional com o seu fazer, na verdade os amores e dissabores que existem na carreira docente. Como lidar com tudo isso? A experiência como monitora era muito mais complexa do que eu pensava ser, suas dimensões atribuíam habilidades muito diferentes e tudo neste fazer começou a chamar-me a atenção, pois suas ações transitavam dentro da rotina mais simples das atividades de professor, por exemplo, fazer chamada, ou como acontece a ação da apreensão dos conteúdos científicos dentro desta relação do apreender para ensinar, a necessidade de saber lidar com as pessoas, acima de tudo ter empatia, sensibilidade e bom senso, e ter a percepção de que as questões de aprendizagem mexem muito com o íntimo das pessoas, sem esquecer as questões administrativas das instituições de ensino, as políticas públicas para educação que mudam a todo tempo.

$\mathrm{Na}$ verdade, o que eu queria entender é como acontece na monitoria esta formação tão complexa que é a docência, as possibilidades e trajetórias que este espaço produz, pelas narrativas das histórias daqueles que estão neste lugar. Não tenho a ilusão de que as reflexões que faço neste texto serão parecidas ou significadas da mesma forma por outros monitores ao contar suas histórias, mas espero ser surpreendida pela pesquisa, sabendo que cada nova reflexão e significação trarão novos sentidos para essa discussão.

O trecho acima é parte do memorial que escrevi ao iniciar a pesquisa desenvolvida no contexto do meu curso de mestrado. Esta pesquisa teve como temática central a monitoria, sendo seu principal objetivo discutir os reflexos da produção de sentidos sobre a formação de professores a partir da experiência vivida por discentes e docentes que participam ou participaram de um Programa de Monitoria em uma universidade federal localizada no Estado do Rio de janeiro. 
No memorial apresento a narrativa da minha história de vida e formação até o momento de meu encontro com a monitoria, a partir daí desenvolvo uma reflexão sobre a atividade de monitoria e seus reflexos nos processos de formação e vida de algumas pessoas que participam ou participaram deste programa. Escrever sobre a monitoria e como ela se construiu como experiência para mim, foi fundamental porque até o momento da escrita do memorial reconheço que não tinha desenvolvido ainda uma reflexão aprofundada sobre todos os acontecimentos que me levaram a ter a monitoria como tema de pesquisa. A escrita do memorial é um exercício reflexivo entre a leitura dos acontecimentos e a escrita da palavra, que me levaram a ampliar a minha formação e a conhecer outros modos de pensar a formação e a docência.

Olhar pelo retrovisor do tempo vivido os contextos de nossa própria história, que em um determinado momento tinham um significado, propicia este movimento retroativo da narrativa, ampliando em muitas vezes seus sentidos e relevância. Posso dizer que esta ampliação de olhar sobre a minha formação aconteceu com a colaboração desta escrita narrativa que foi descortinando sentidos e significados aos acontecimentos sobre a minha formação docente. No momento em que estava vivenciando os processos de monitoria, eu não tinha uma percepção muito clara de sua importância para o meu processo formativo. Esse momento de reflexão sobre o que foi vivido e que aconteceu através da palavra escrita em uma narrativa que chamamos de memorial, foi o que me fez compreender melhor os processos da formação que foram se constituindo para mim.

Por que isso acontece? Penso que esta reflexão sobre as dimensões do vivido, que a narrativa proporciona, oferece uma oportunidade de autoformação, uma colaboração sem precedentes a todo um processo formativo que vai nos constituindo como professores, mas que precisa deste (re)ver para uma análise plena do processo. A escrita do memorial de formação foi para mim, exercício de rememoração do vivido, percepção de uma vida no trajeto de uma formação e na compreensão de que a formação docente vai muito além dos aspectos de ensino e aprendizagem, mas que reside nas dimensões das interações entre alunos, professores orientadores e monitores.

\section{PUXANDO OS FIOS DO DIÁLOGO ENTRE PALAVRAMUNDO E PESQUISAFORMAÇÃO}

Foram muitos os fios que fomos puxando e descobrindo ao longo da escrita deste texto, e apesar de revisitarmos textos já por nós conhecidos, esse movimento de construir esse diálogo entre a ideia de palavramundo e pesquisaformação, trouxe um novo brilho à importância de que pesquisar é reler, rever sobre uma outra perspectiva, mas não a única possível, uma experiência de vida e conhecimento que possa acrescentar algo à conversa e a reflexão dos muitos leitores existentes. Produzindo o que Gagnebin (2013), referindo-se à concepção de Benjamin sobre a arte de contar, vai chamar de comunidade de experiência, à qual poderíamos acrescentar comunidades narrativas, nas quais o fluxo narrativo se abre à novas propostas de leitura, de reflexões e conversas.

O diálogo, por vezes, também acontece por meio do revisitar o já vivido. Escrever sobre algum tema que emerge da vasta obra de Paulo Freire é produzir essa (re)visita aos seus escritos e aos seus ensinamentos sobre a indissociabilidade entre vida, educação, política, palavramundo, formação. Em tempos sombrios como os que atravessamos, fazer essa (re)visita de leitura e escrita possui duplo sentido: de resistência aos desafios educacionais que estamos atravessando, em especial nos últimos dois anos, e de homenagem ao incansável trabalho de Paulo Freire sobre, com e para o povo brasileiro, trabalho que sempre nos possibilita aprender sobre formação, docência e sobre como o outro aprende e lê o mundo. 
Nas histórias e trajetórias contadas nos memoriais tão caros à pesquisa narrativa, como o registro da palavramundo do pesquisador, de como o tema de sua pesquisa se gestou emaranhado em suas experiências, há um convite de compartilhamento, de se dar a conhecer ao outro e a si mesmo, propondo sempre a continuidade de uma reflexão. A ideia de pesquisaformação vai adquirindo contornos maravilhosos quando nos permite ver, (re)ver, que aquele tema já estava presente em nossa história de vida muito antes de que pudéssemos dar conta e assim também contamos a nós mesmos essa aventura de conhecimento.

Uma das potencialidades da tessitura entre as histórias de vida, sua escrita no memorial e a palavramundo, está inscrita na atribuição de sentido às experiências de vida e formação, mas as extrapola porque nos formamos em diálogo com o outros, como nos ensinou Paulo Freire, e as nossas histórias não são somente nossas. Nós as escrevemos, mas elas também são das muitas vozes que nos constituem, e nos auxiliam a afirmar em diálogo com Paulo Freire, que a profissão professor é um ato político, pessoal e social, que necessita de formação específica, porém não dissociada da vida de quem se forma, mas uma formação que nos auxilie a produzir conhecimento sobre e com nossas experiências de vida e na vida.

\section{REFERÊNCIAS}

ALVES, Nilda. Nós somos o que contamos: a narrativa de si como prática de formação. In: SOUZA, Elizeu Clementino de; MIGNOT, Ana Chrystina Venancio (org.). Histórias de vida e formação de professores. Rio de Janeiro: Quartet: FAPERJ, 2008, p.131-145.

BOMBASSARO, Luiz Carlos. Hermenêutica. In: STRECK, Danilo R.; REDIN, Euclides Redin; ZITKOSKI, Jaime José (org.). Dicionário Paulo Freire. Belo Horizonte: Autêntica Editora, 2010, p. 204-206.

BRAGANÇA, Inês Ferreira de Souza. Pesquisaformação narrativa (auto)biográfica: trajetórias e tessituras teórico-metodológicas. In: ABRAHÃO, Maria Helena Menna Barreto; CUNHA, Jorge Luiz da Cunha; BÔAS, Lúcia Villas (org.). Pesquisa (auto)biográfica: diálogos epistêmicometodológicos. Curitiba: CRV, 2018, p. 65-81.

BRAGANÇA. Inês Ferreira de Souza. Histórias de vida e formação de professores: diálogos entre Brasil e Portugal. Rio de Janeiro: EdUERJ, 2012.

CASALI, Alípio. Os gêneros de texto na obra de Paulo Freire: um legado pedagógico e literário. Revista e-Curriculum, v. 10, n. 3, p. 53-73, 2012. Disponível em: https://www.redalyc.org/articulo.oa?id=76624994004. Acesso em 25 ago. 2021.

CUNHA, Maria Isabel da. Narrativas e formação de professores: uma abordagem emancipatória. In: SOUZA, Elizeu Clementino de; GALLEGO, Rita de Cassia (org). Espaços, tempos e gerações. São Paulo: Cultura Acadêmica, 2010, p. 199-213.

DELORY-MOMBERGER, Christine. Abordagens metodológicas na pesquisa biográfica; tradução de Anne-Marie Milon Oliveira; revisão técnica de Fernando Scheibe. Revista Brasileira de Educação, v. 17, n. 51, p. 523-740, 2012. Disponível em https://www.scielo.br/j/rbedu/a/5JPSdp5W75LB3cZW9C3Bk9c/abstract/?lang=pt. Acesso em 23 ago. 2021.

FERRAROTTI, Franco. Sobre a autonomia do método biográfico. In: NÓVOA, António; FINGER, Matthias (org.). O método (auto)biográfico e a formação; tradução de Maria Nóvoa. Natal, RN: EDUFRN; São Paulo: Paulus, 2014, p. 29-55. 
FREIRE, Paulo. Professora, sim; tia, não: cartas a quem ousa ensinar. Rio de Janeiro/ São Paulo: Paz e Terra, 2021.

FREIRE, Paulo. Pedagogia da esperança: um reencontro com a pedagogia do oprimido; prefácio de Leonardo Boff; notas de Ana Maria Araújo freire. $-28^{\circ}$ ed. São Paulo/Rio de Janeiro: Paz e Terra, 2021.

FREIRE, Paulo; SHOR, Ira. Medo e ousadia: o cotidiano do professor; tradução Adriana Lopes; revisão técnica Lólio Lourenço de Oliveira. - 4. Ed. - São Paulo: Paz e terra, 2021.

FREIRE, Paulo; GUIMARÃES, Sérgio. Aprendendo com a própria história. - São Paulo: Paz e Terra, 2021.

FREIRE, Ana Maria Araújo. A leitura do mundo e a leitura da palavra em Paulo Freire. Caderno Cedes, Campinas, v. 35, n. 96, p. 291-298, 2015. Disponível em https://www.scielo.br/j/ccedes/a/7DgKZW4TQjBFXd9BTnvrQwv/?lang=pt\&format=pdf. Acesso em 24 ago. 2021.

FREIRE, Paulo. A importância do ato de ler: em três artigos que se complementam. São Paulo: Cortez, 2011.

FREIRE, Paulo. $A$ importância do ato de ler: em três artigos que se completam. São Paulo: Autores Associados: Cortez, 1989.

FREIRE, Paulo. Da leitura do mundo à leitura da palavra; Entrevista concedida a Ezequiel Theodoro. Leitura: teoria e prática, Porto Alegre, v. 1, n. 0, nov., 1982, p. 3-9. Disponível em http://acervo.paulofreire.org:8080/xmlui/handle/7891/2842. Acesso em 23 ago. 2021.

GADOTTI, Moacir. Saber aprender: um olhar sobre Paulo Freire e as perspectivas atuais da educação. In: Congresso Internacional Um olhar sobre Paulo Freire. Évora, 2000, p. 1-10. Disponível em http://acervo.paulofreire.org:8080/xmlui/handle/7891/1125. Acesso em 23 ago. 2021.

GAGNEBIN, Jeanne Marie. Prefácio. In: BENJAMIN, Walter. Magia e técnica, arte e politica: ensaios sobre literatura e história da cultura; tradução de Sérgio Paulo Rouanet; prefácio de Jeanne Marie Gagnebin. - 8. ed. revista -. São Paulo: Brasiliense, 2012. p. 7-19.

JOSSO, Marie-Christine. Experiências de vida e formação. São Paulo: Cortez, 2004

KOHAN, Walter. Paulo Freire, mais do que nunca: uma biografia filosófica. 1. Ed. - Belo Horizonte: Vestígio, 2019.

LEAL, Sandra do Rocio Ferreira; NASCIMENTO, Maria Isabel Moura. A importância do ato de ler: aproximações e distanciamentos teórico-metodológicos em Paulo Freire. Pro-Posições, Campinas, v. 30, e20180024, p. 1-23, 2019. Disponível em https://www.scielo.br/j/pp/a/GTyQPNPxDs5n5m4ZB5nbcdR/?lang=pt\&format=pdf. Acesso em 23 ago. 2021.

MOTTA, Thais da Costa; BRAGANÇA, Inês Ferreira de Souza. Pesquisaformação: uma opção teórico-metodológica de abordagem narrativa (auto)biográfica. Artes de dizerfazerdizer os saberes da experiência. Revista Brasileira de Pesquisa (Auto)Biográfica, v. 4, n. 12, p. 1034-1049, 2019. Disponível em: https://www.revistas.uneb.br/index.php/rbpab/article/view/6191. Acesso em 25 ago. 2021.

NÓVOA, António. A formação tem que passar por aqui: as histórias de vida no Projeto Prosalus. In: NÓVOA, António; FINGER, Matthias (org.). O método (auto)biográfico e a formação; tradução Maria Nóvoa. Natal, RN: EDUFRN; São Paulo: Paulus, 2014, p. 143-175. 
NÓVOA, António. Os professores e as histórias de sua vida. In: NÓVOA, Antônio (org.). Vidas de professores. - 2. ed. - Portugal: Porto Editora, 1992, p. 11-17.

PASSEGGI, Maria da Conceição; SOUZA, Elizeu Clementino de. O movimento (Auto)Biográfico no Brasil: esboço de suas configurações no campo educacional. Investigación Cualitativa, v. 2, n. 1, p. 6-26, 2017.

PASSEGGI, Maria da Conceição. Memorial de formação. In: OLIVEIRA, Dalila Andrade; DUARTE, Adriana Maria Cancela; VIEIRA, Lívia Maria Fraga. Dicionário: trabalho, profissão e condição docente. Belo Horizonte: UFMG/Faculdade de Educação, 2010. CDROM, p. 1-4.

PASSEGGI, Maria da Conceição; BARBOSA, Tatyana Mabel Nobre. Apresentação. In: PASSEGGI, Maria da Conceição; BARBOSA, Tatyana Mabel Nobre (org.). Memórias, memoriais: pesquisa e formação docente. Natal, RN: EDUFRN; São Paulo: Paulus, 2008, p. 15-24.

SILVA, Ezequiel Theodoro da. Prefácio à 51a edição. In: FREIRE, Paulo. A importância do ato de ler: em três artigos que se completam. São Paulo: Cortez, 2011. p. 9 - 12.

SILVA, Ezequiel Theodoro da. $O$ ato de ler: fundamentos psicológicos para uma nova pedagogia da leitura. São Paulo: Cortez: Autores Associados, 1991.

\section{Informações das autoras}

Eda de Oliveira Henriques

Universidade Federal Fluminense

E-mail:edahenriques@gmail.com

ORCID: https://orcid.org/0000-0002-7240-5520

Link Lattes: http://lattes.cnpq.br/1978216840303181

Heriédna Cardoso Guimarães

Universidade Federal Fluminense

E-mail:heriedna@gmail.com

ORCID: http://orcid.org/0000-0003-0388-924X

Link Lattes: http://lattes.cnpq.br/0041496560292967

Verônica Fabiola Neves Rodrigues

Universidade Federal Fluminense

E-mail:veronicafabiola@id.uff.br

ORCID: https://orcid.org/0000-0001-9657-5850

Link Lattes: http:// lattes.cnpq.br/9604135036188842 